* Mestranda em Direito pelo Programa de Pós-graduação da Instituição Toledo de Ensino (ITE). Pós-graduada em Direito Civil e Processo Civil pela Universidade Estadual de Londrina (UEL) e em Direito Aplicado pela Escola da Magistratura do Paraná (EMAP). E-mail: liviapzamarian@hotmail.com ** Professor Livre-docente de Direito Constitucional da PUCSP e do Programa de PósGraduação da Instituição Toledo de Ensino (ITE/ Bauru). E-mail: serrano-jr@uol.com.br

\section{Súmulas vinculantes: solução para \\ a adequada abstrativização do controle difuso de constitucionalidade?}

\author{
BINDING DECISIONS: SOLUTION TO PROPER \\ DIFFUSE CONTROL'S ABSTRACTION?
}

\author{
Lívia Pitelli Zamarian * \\ Vidal Serrano Nunes Jr **
}

Resumo: O artigo aborda as características atuais do sistema de controle de constitucionalidade brasileiro, em especial a almejada abstrativização do controle difuso. Para tanto, estuda a teoria da inconstitucionalidade, os sistemas de controle, o hibridismo brasileiro e a sua mitigação através da abstrativização, que almeja objetivar o controle difuso, imputando-lhe efeitos típicos do controle abstrato. Além de analisar os benefícios e prejuízos desta tendência, investiga as súmulas vinculantes como forma adequada de implantá-la no ordenamento jurídico brasileiro para regular concessão de efeito erga omnes e vinculante às decisões de controle difuso de constitucionalidade sem participação do Senado Federal.

Palavas-chave: Súmula Vinculante. Controle de Constitucionalidade. Abstrativização. Supremo Tribunal Federal.

Abstract: The article deals with the current characteristics of the Brazilian system of judicial review, specially the diffuse control's abstraction. In order to do that, it studies the unconstitutionality theory, the Brazilian judicial review system and its mitigation through the "abstraction" which aims to object the diffuse control, charging it with the typical effects of the abstract control. Besides evaluating the benefits and drawbacks of this trend, it investigates the binding docket as a proper way of using it in the Brazilian legal system, and granting the binding and erga omnes effects to the diffuse control's decisions without the Senate participation.

Keywords: Binding Docket. Constitutionality Control. Abstrativization. Brazilian Supreme Court. 


\section{INTRODUÇÃO}

O controle de constitucionalidade brasileiro vem se modificando ao longo dos anos. Estas mudanças vêm sendo acompanhadas pela jurisprudência do Supremo Tribunal Federal que, a cada dia mais, amealha poderes para si. Uma destas alterações implica na mitigação entre a separação das formas de controle de constitucionalidade, com objetivo de aplicar efeitos típicos do controle concentrado ao controle difuso. É a chamada abstrativização do controle difuso, objeto de estudo do presente artigo após uma breve análise da teoria da inconstitucionalidade, a supremacia constitucional, as espécies de inconstitucionalidade e os sistemas de controle, em especial o hibridismo brasileiro.

A abstrativização promete inúmeros benefícios à celeridade e economia processuais, além de reforço à segurança jurídica em razão da uniformização de jurisprudência provocada. Por outro lado, ofende a norma constitucional pátria ao desrespeitar diversos de seus dispositivos, como analisado na primeira parte do trabalho. Uma das saídas vislumbradas para a viabilização da aplicação de tal objetivação é a utilização do procedimento previsto para a edição de súmulas vinculantes. Assim, na segunda parte do trabalho analisa-se a sua criação, seu procedimento e o efeito vinculante para, ao final, investigar sobre sua viabilidade como forma de regular abstrativização do controle difuso de constitucionalidade.

\section{CONTROLE DE CONSTITUCIONALIDADE}

As constituições, como documentos jurídico-normativos que são, caracterizam-se como os documentos mais importantes de uma nação e de seu povo, já que objetivam proteger os anseios sociais, as decisões políticas e os direitos fundamentais de seus cidadãos.

\subsection{A Supremacia Constitucional}

As constituições precisam se amoldar à evolução social e às novas situações fáticas e demandas surgidas, não podendo, portanto, ser imutáveis. Não podem, porém, ser alteradas ao bel prazer dos legisladores sob pena de tornarem-se inconstantes. Busca-se um equilíbrio entre "estabilidade e adaptabilidade", estabelecendo-se procedimentos específicos e complexos para sua alteração, conferindo-lhe rigidez (BARROSO, 2009, p.141). É esta rigidez 
que garante supremacia ao texto constitucional, colocando-o em posição superior no ordenamento jurídico, já que, segundo Kelsen (2006, p.247) “cria uma relação piramidal entre esta e as demais normas do mesmo ordenamento jurídico, que com ela devem guardar relação de necessária lealdade". Assim, a Constituição adquire status de norma fundamental de um sistema jurídico, e passa a ser o fundamento de validade das demais normas inferiores:

A ordem jurídica não é um sistema de normas jurídicas ordenadas no mesmo plano, situadas umas ao lado das outras, mas é uma construção escalonada de diferentes camadas ou níveis de normas jurídicas. A sua unidade é produto da conexão de dependência que resulta do fato de a validade de uma norma, que foi produzida de acordo com outra norma, se apoiar sobre essa outra norma, cuja produção, por sua vez, é determinada por outra; e assim, por diante, até abicar finalmente da norma fundamental - pressuposta. A norma fundamental - hipotética, nestes termos - é, portanto, o fundamento de validade último que constitui a unidade desta interconexão criadora. Se começarmos levando em conta apenas a ordem jurídica estadual, a Constituição representa o escalão do Direito positivo mais elevado. (KELSEN, 2006, p.247).

A norma constitucional é responsável por conferir unidade a todas as outras que o compõem - em relação às quais apresenta supremacia formal e material. Esta superioridade hierárquica, para Canotilho (1991, p.141), manifestase em três perspectivas: constitui “uma 'lex superior' que recolhe o fundamento de validade em si própria"; é fonte de produção de outras normas; e regula a todos os atos dos poderes políticos que necessariamente, com elas devem estar conformes.

É por gozar de supremacia, que todas as demais normas infraconstitucionais devem se harmonizar com o Texto Maior, sob pena de, em contrariando-o, serem inconstitucionais. "A relação de inconstitucionalidade é uma relação entre dois graus de ordem jurídica, estando as normas e actos no grau inferior" (MIRANDA, 1996, p.19).

\subsection{Sistemas de Controle de Constitucionalidade}

Para ceifar a inconstitucionalidade e preservar a autoridade de sua norma fundamental, os Estados Democráticos de Direito que possuem uma constituição rígida e escrita, adotam meios de fiscalização e adequação das leis e atos 
normativos que se afastarem da norma constitucional. São os chamados controles de constitucionalidade que tem como escopo "instituir barreiras à introdução de normas inconstitucionais no cenário jurídico" ou reconhecer a "inexistência da norma institucional no sistema" (ARAUJO; NUNES JR., 2006, p.25).

O controle de constitucionalidade foi inicialmente criado nos Estados Unidos da América e ganhou visibilidade em 1803, com o caso Madison X Marbury onde John Marshall, juiz da Suprema Corte americana, declarou inconstitucional uma lei hierarquicamente inferior á Constituição. Surgiu assim o controle difuso de constitucionalidade, que promove, por via de exceção, a análise da lei em um caso concreto. Neste sistema, "o poder de controle pertence a todos os órgãos judiciários de um dado ordenamento jurídico, que o exercitam incidentalmente, na ocasião da decisão das causas de suas competências" (CAPPELLETTI, 1999, p.67). As decisões daí advindas operam efeitos somente inter partes.

Por meio de Hans Kelsen, idealizador da Constituição austríaca de 1920, surgiu também outra forma de controle de constitucionalidade: o controle concentrado, realizado exclusivamente por um Tribunal Constitucional que analisa a lei em tese, em abstrato, e declara a inconstitucionalidade com efeito erga omnes.

Ambas estas formas, que são as mais comuns, tratam-se de modalidades de controle repressivo, ou seja, visam expurgar a norma após esta já ter adentrado no ordenamento jurídico e, em regra, são realizados pelo Judiciário, mas podem também ser feitas pelo Legislativo ou até pelo Executivo. O controle pode ser executado de forma preventiva pelo Poder Executivo, Legislativo ou Judiciário, visando impedir que a norma inconstitucional ingresse no ordenamento jurídico, como faz o Conselho Constitucional Francês, que controla a priori a constitucionalidade das leis orgânicas e ordinárias (FAVOREU, 2004).

\subsection{O Hibridismo Brasileiro}

Instituído pela Constituição dos Estados Unidos do Brasil em 1891, o controle judicial de constitucionalidade brasileiro, que até então era eminentemente político, surgiu na forma incidental difusa, operando efeito somente inter partes. Com a Constituição da República dos Estados Unidos do Brasil de 1934 esta forma de controle foi aprimorada: passou a exigir a reserva de plenário para a declaração de inconstitucionalidade de tribunais, 
mas ganhou a possibilidade de operar efeito erga omnes com a participação do Senado Federal ${ }^{1}$.

A própria Constituição de 1934 introduziu também a ação direta, "como procedimento preliminar do processo interventivo" (MENDES, 2004b, p.240) e meio de proteção dos princípios fundamentais sensíveis, dando indícios de criação do controle abstrato, muito embora tal medida tivesse um caráter mais concreto (CLÈVE, 2000, p.139-140). Somente em 1965, contudo, com o advento da Emenda n. 16 à Constituição de 1946, que criou a Ação Direta Genérica de inconstitucionalidade (ADI) é que o controle concentrado e abstrato se consolidou, passando a coexistir com a forma difusa de controle de constitucionalidade. Deste então, até a Constituição atual, o ordenamento jurídico brasileiro passou a adotar um sistema de controle peculiar: o controle híbrido ou misto, que admite tanto o controle abstrato concentrado como o controle concreto difuso.

Admite-se também o controle pelo Legislativo, de forma preventiva (art. $58, \mathrm{CF}$ ) e repressiva (arts. 49, $\mathrm{V}$ e $62, \S 5^{\mathrm{o}} 2, \mathrm{CF}$ ) e pelo Executivo de forma preventiva (art. $66, \S 1^{\circ}, \mathrm{CF}$ ), e até se cogita a realização do controle repressivo pelo Executivo ${ }^{3}$ e preventivo pelo Judiciário ${ }^{4}$. Apesar disso, as modalidades mais expressivas de controle no nosso ordenamento são aquelas realizadas de maneira repressiva pelo Poder Judiciário: seja de forma abstrata ou concreta.

O controle abstrato é aquele realizado mediante o exame da inconstitucionalidade em tese. Geralmente é feito de forma concentrada, sendo, no Brasil, o Supremo Tribunal Federal o órgão competente para tanto, mas que, por cumular também outras funções, não é um verdadeiro Tribunal Constitucional (CLÈVE, 2000, p.141). Tem como objeto principal a constitucionalidade ou inconstitucionalidade de determinada lei e a decisão daí advinda produzirá coisa julgada material, terá eficácia erga omnes e, atualmente, também vinculante. A lei ou ato normativo declarado inconstitucional será nulificado e perderá sua validade.

\footnotetext{
${ }^{1}$ A participação do senado Federal foi excluída na Constituição de 1937, mas foi restaurada com o advento da Constituição de 1946.

${ }^{2}$ Sobre o assunto consultar Moraes (2000, p.561).

${ }^{3} \mathrm{O}$ descumprimento de lei considerada como inconstitucional pelo Executivo não é expressamente admitido pela CF88, mas parece ser aceito pela jurisprudência do STF (ADI 221 MC, j. 29/03/1990) e do STJ (REsp 23121/GO, j.06/10/1993).

${ }^{4}$ Este foi o entendimento do STF no julgamento do MS 22503, j.08/05/1996, quando admitiu Mandado de Segurança impetrado por parlamentares para pleitear a garantia do devido processo legislativo, na defesa do chamado “direito-função" do parlamentar de participar de um processo legislativo juridicamente hígido” (ARAÚJO; NUNES JR., 2006, p.25).
} 
Já o controle difuso-concreto é a forma de controle que pode ser exercida por qualquer órgão jurisdicional e normalmente é realizada de forma concreta, ou seja, a posteriori, à luz das minúcias do caso concreto. A constitucionalidade sempre será questão incidente, resolvida na fundamentação da decisão judicial e produzirá efeito somente entre as partes. As decisões obtidas anulam a lei, retirando sua eficácia somente naquele caso concreto, e, tradicionalmente, só poderão adquirir efeito erga omnes se declarada a suspensão pelo Senado Federal (art. 52, X, CF).

\section{NOVA TENDÊNCIA NO CONTROLE DE CONSTITU- CIONALIDADE: A ABSTRATIVIZAÇÃO DO CONTROLE DIFUSO}

Apesar da distinção tradicional, o controle de constitucionalidade brasileiro vem enfrentando mudanças e tendências ao longo da história e, em especial na última década. O modelo híbrido adotado é considerado um dos mais completos do mundo, por abranger tanto o controle abstrato-concentrado como o concretodifuso. Para Bonavides (1994) ${ }^{5}$, o emprego das duas técnicas, cada uma com uma função é uma evolução doutrinária e institucional. Sofre, contudo, duras críticas, inclusive sob a pecha de causar uma "crise de governabilidade" já que a combinação de dois sistemas demonstra que "o papel do Judiciário na vida política não está institucionalmente definido" e chega-se até a sugerir a extirpação do controle difuso (ARANTES, 1997. p.204).

Apesar de no ordenamento jurídico brasileiro coexistirem sistemas de controle com características próprias e bem delineadas, recentemente nota-se certa mitigação desta separação. $\mathrm{O}$ controle difuso, que sempre foi superior (MARINONI, 2010, p.78), e ainda o é de forma quantitativa, perdeu um pouco de espaço em importância para o controle concentrado, especialmente após a instituição da Ação Direta Genérica de Inconstitucionalidade. O controle

\footnotetext{
5 "O controle por via de exceção é de sua natureza o mais apto a prover a defesa do cidadão contra os atos normativos do Poder, porquanto em toda demanda que suscite controvérsia constitucional sobre lesão de direitos individuais estará sempre aberta uma via recursal à parte ofendida. A latitude de iniciativa da sindicância de constitucionalidade, em se tratando da via direta, é decisiva para marcarlhe a feição liberal ou estatal, democrática ou autoritária, em ordem a determinar se o controle se faz com o propósito de atender aos fins individuais ou aos interesses do Estado, interesses que tanto podem exprimir uma necessidade de harmonia na relação entre os distintos órgãos da soberania como um impulso de expansão e hegemonia de um dos poderes, nomeadamente o Executivo". (BONAVIDES, 1994. p.294.)
} 
concentrado ganhou força também com a ampliação do rol dos legitimados ativos para sua propositura, com a criação da ADI por omissão e da Ação de Descumprimento de Preceito Fundamental (ADPF), e a criação de efeito vinculante pela Emenda Constitucional n. 3/93.

Clémerson Clève adverte que: "A convivência dos modelos concentrado e difuso continua, todavia, a fiscalização abstrata e concentrada registra, passo a passo, e de modo preocupante, uma significação cada vez mais preocupante" (CLÈVE, 2000, p.140).

É notória a sensível diminuição da importância do sistema difusoincidental e isso se reflete na jurisprudência da própria Suprema Corte que passou a admitir a utilização de institutos tradicionais do controle abstrato no controle concreto, tais como a intervenção do amicus curiae 6 , a modulação dos efeitos de declaração de inconstitucionalidade ${ }^{7}$ e a aceitação da causa pretendi aberta ${ }^{8}$.

Até o legislador, nesta mesma tendência, inseriu, através da Emenda Constitucional n. 45/2004, um elemento objetivo no controle concreto de constitucionalidade: a repercussão geral como requisito de admissibilidade do recurso extraordinário. Este instituto permite que o STF selecione para julgamento apenas as questões constitucionalmente relevantes e que transcendem o interesse das partes. Nesta mesma toada, o legislador já havia possibilitado a prescindibilidade da cláusula de reserva de plenário do art. 97 da CF, através da Lei n. 9756/98 que inseriu o parágrafo único no art. 481 do Código de Processo Civil (CPC) e também instituiu a súmula vinculante pela própria EC 45/2004. Em razão de tais alterações, a jurisprudência e a doutrina constitucionais já vislumbram a possibilidade de concessão de efeitos erga omnes e vinculante a decisões do Plenário do STF em controle concreto de constitucionalidade.

Todas estas mudanças acabam por aproximar o controle difuso do controle concentrado de constitucionalidade contribuindo para sua "abstrativização".

\footnotetext{
${ }^{6}$ Atualmente autorizado pelo art. 543-A do CPC: "O relator poderá admitir, na análise da repercussão geral, a manifestação de terceiros, subscrita por procurado habilitado, [...]".

${ }^{7}$ O leading case que permitiu a modulação foi o RE n.197.917/SP.

${ }^{8}$ Trata-se da possibilidade do STF julgar a questão da constitucionalidade com base em fundamento diverso do que o invocado pela parte ou enfrentado pelo tribunal recorrido, possibilidade típica do controle abstrato, mas já admitida no controle concreto pelo STF, nos seguintes recursos: RE n.298.694, SE AgR n.5206.
} 


\subsection{A abstrativização: o que é?}

Já explicitada na jurisprudência e chancelada por grande parte da doutrina, a "abstrativização" ou "objetivação" do controle difuso de constitucionalidade é uma tentativa de conceder-lhe efeitos erga omnes e vinculante aos seus julgamentos, sem qualquer participação do Senado Federal.

Tal movimento foi impulsionado pelo assoberbamento do Supremo Tribunal brasileiro, que demandou mudanças.

O crescimento do Supremo Recursal verificado a partir de 1997 chegou a ponto de pôr em xeque a capacidade do próprio Supremo de se autogerir. Os recursos chegaram às centenas de milhares e continuavam a crescer até 2007. Em outras palavras, como dissemos acima, se fossem julgar todos esses processos na mesma proporção em que entravam, cada um dos 11 ministros teria de julgar mais de 10 mil recursos por ano, ou aproximadamente um recurso a cada 10 minutos. Diante desse cenário, tornou-se imperiosa uma nova política de direito processual capaz de conter o acesso ao Supremo. A título de comparação, a Suprema Corte norte-americana recebe cerca de 7 mil processos ao ano e julga aproximadamente 100. O Supremo Tribunal Federal, até 2007, estava recebendo e julgando mais de 100 mil. Fica claro que a agilidade decisória do Supremo não se resolve apenas imprimindo maior velocidade dos processos, mas pressupõe, antes, maior seleção dos casos que ali podem chegar. (FALCÃO; CERDEIRA; ARGUELHES, 2011).

Esta situação caótica tem como causa, segundo Gomes Jr. (2005, p.91), "desde o aumento da procura pelos serviços prestados pelo poder Judiciário, até a irresignação exacerbada do Poder Público em suas várias esferas". Isso fez com que, segundo o autor, o recurso extraordinário (RE) - principal instrumento de controle difuso brasileiro, "que deveria ser extraordinário [...] tornou-se ordinaríssimo", e relegou o STF para um mero terceiro ou quarto grau de jurisdição.

Aliado ao grande número de processos, outro pretexto para as transformações é o risco de ofensa à igualdade das decisões, à insegurança jurídica e à certeza das decisões judiciais, além do conflito entre os órgãos judiciários que a ausência de respeito a decisões do Plenário do STF possam acarretar.

\footnotetext{
${ }^{9}$ Esta expressão foi utilizada pela primeira vez por DIDIER JÚNIOR (2006).
} 
Não só a doutrina clamava pela objetivação, mas também a jurisprudência. No ano de 2003, Gilmar Mendes já defendia a objetivação de processos subjetivos com o recurso extraordinário, que "deixa de ter caráter marcadamente subjetivo ou de defesa de interesse das partes, para assumir, de forma decisiva, a função de defesa da ordem constitucional objetiva"10, como forma de racionalizar a prestação jurisdicional, o que foi também defendido pela Ministra Ellen Gracie ${ }^{11}$. Tal posicionamento, segundo Marinoni (2010, p. 81-82), também foi repetido textualmente quando do julgamento do mérito do RE 376.852 e da Reclamação (RCL) n.2986, por exemplo. Em 1997, no julgamento do RE 191.898, a $1^{\text {a }}$ Turma do STF já havia manifestado a possibilidade de visualizar efeito vinculante nas decisões do recurso extraordinário, quando dispensou a análise da inconstitucionalidade pelo plenário dos tribunais, nas hipóteses em que o pleno já houvesse se manifestado a respeito. Nesse sentido, há decisão que chegaram até a determinar a vinculação das Turmas aos precedentes do Plenário ${ }^{12}$, excetuando-se somente proposta de revisão de qualquer dos Ministros.

Esta tendência jurisprudencial logo foi reforçada pela criação da repercussão geral como requisito de admissibilidade do recurso extraordinário, que notadamente é um requisito de objetivação deste recurso. Assim, ele passou a ser apenas um "pressuposto para a atividade jurisdicional que transcende os interesses subjetivos" (DIDIER JÚNIOR, 2006, p.984.).

Note-se que a justificativa para a aproximação entre os dois modelos de controle de constitucionalidade é que, quando ambos são realizados pelo Plenário da Corte obedecem a procedimentos muito semelhantes e, portanto, "não existe qualquer razão plausível para se atribuir efeito vinculante a um modelo e não ao outro" (MARINONI; MITIDIEIRO, 2007, p.69). É o que também afirma Mendes:

De qualquer sorte, a natureza idêntica do controle de constitucionalidade, quanto ás suas finalidades e aos procedimentos comuns dominantes para os modelos difuso e concentrado, não mais parece legitimar a distinção quanto aos efeitos das decisões proferidas no controle direto e no controle incidental. (MENDES, 2004a, p.164).

\footnotetext{
${ }^{10}$ STF, Pleno, RE 376852 MC. Relator: Min. Gilmar Mendes. J.27/03/2003.

${ }^{11}$ STF, Segunda Turma, AI 375011 AgR. Relatora: Min. Ellen Gracie, j.05/10/2004.

${ }^{12}$ STF, RE 244048-AgR/SP, Relator: Min. Celso de Mello. Brasília, j.15/04/2005.
} 
Assim, por abstrativização, pode-se entender a concessão de efeitos erga omnes e vinculante, característico do controle concentrado e abstrato de constitucionalidade, às decisões de controle difuso e concreto. A intenção daqueles que defendem esta objetivação é fazer com que as decisões proferidas pelo STF em controle difuso ganhem interpretação extensiva, vinculando horizontal e verticalmente, "independentemente da existência de enunciado sumular de eficácia vinculante" sob o argumento de "evitar decisões contraditórias e acelerar o julgamento das demandas" (DIDIER JÚNIOR, 2006, p.983-986).

Em relação ao Supremo, havia uma decisão que prometia resolver grande parte deste conflito sobre: a RCL n. 4335-5/AC, em trâmite desde 2006 e ainda pendente de julgamento. Nela, o reclamante pleiteia a aplicação em sua demanda da decisão tomada pelo STF no Habeas Corpus (HC) n. $82959^{-}$que reconheceu incidentalmente (ou seja, em controle difuso) a inconstitucionalidade do dispositivo que proíbe a progressão de regime de cumprimento de pena nos crimes hediondos (art. $2^{\circ}, \S 2^{\circ}$, da Lei n. 8072/90). O reclamante alega que teve seu pedido de progressão negado em primeiro grau, sob o argumento de que a decisão do STF não se aplicaria obrigatoriamente àquele caso concreto vez que, se deu em controle difuso de constitucionalidade e, portanto, só tem efeito inter partes.

A decisão sobre esta reclamação era aguardada com ansiedade no meio jurídico, já que através dela o Supremo foi incitado a se manifestar sobre os feitos do controle difuso, ora discutido. Para Streck, Oliveira e Lima (2010, p.01), tal votação poderia trazer novas concepções de controle de constitucionalidade no Brasil e reflexamente do poder constituinte, equilíbrio entre os Poderes da República e Sistema Federativo. Tal expectativa deve, contudo, ser frustrada ante a edição da súmula vinculante n. $26^{13}$.

\subsection{Os benefícios à celeridade, economia e eficácia processuais}

Segundo os defensores da objetivação do controle difuso realizado pelo STF, como já mencionado, não há razão para manutenção da distinção entre os efeitos das decisões advindas de uma ou outra forma de controle. Para Barroso

\footnotetext{
${ }^{13}$ Súmula Vinculante n.26: "Para efeito de progressão de regime no cumprimento de pena por crime hediondo ou equiparado, o juízo da execução observará a inconstitucionalidade do art. $2^{\circ}$ da Lei 8072 , de 25 de julho de 1990, sem prejuízo de avaliar se o condenado preenche, ou não, os requisitos objetivos e subjetivos do benefício, podendo determinar, para tal fim, de modo fundamentado, a realização de exame criminológico."
} 
(2008, p.122.) não há que se cogitar em diferenciação dos efeitos entre o controle direto e o indireto já que "seria uma demasia, uma violação ao princípio da economia processual, obrigar um dos legitimados do art. 103 a propor ação direta para produzir uma decisão que já se sabe qual é!" Além disso, a abstrativização tem o condão de conferir maior eficácia e racionalização nos julgamentos do STF:

Há, ai, mais um instrumento para consecução da unidade do Direito por intermédio da compatibilização das decisões judiciais. Uma vez já decidida a questão, qualquer nova apreciação, sem o fito da revisão da tese, importa em dilação indevida no processo da causa. Encurta-se o procedimento, com flagrante economia dos atos processuais. (MARINONI; MITIDIEIRO, 2007. p.27).

É a promessa, portanto, de agilização na prestação jurisdicional pela Suprema Corte através de uma "forma de evitar decisões contraditórias e acelerar o julgamento das demandas” (DIDIER JÚNIOR, 2006. p.983-986). Com a redução do tempo de tramitação e até do número de recursos admitidos pelo STF, permite-se que ao invés de atuar como revisor de "pronunciamentos de Corte Inferiores", solucionador de "litígios de fulano ou beltrano" (DIDIER JÚNIOR, 2006. p.983), ele seja "reconduzido à sua verdadeira função, que é a de zelar pelo direito objetivo - sua eficácia, sua inteireza e a uniformidade de sua interpretação" (WAMBIER; WAMBIER; MEDINA, 2007, p.241). Essa transformação beneficia a eficácia da prestação jurisdicional que será mais homogênea para casos idênticos, e propiciará ao cidadão uma sensação maior de "justiça".

A ausência de uma jurisprudência relativamente uniforme é um problema crônico no Brasil. Isto se dá, principalmente, segundo Wambier e Wambier (2009, p.06), pela possibilidade de no sistema do civil law os juízes poderem decidir "de acordo com suas próprias opiniões a respeito do sentido da lei"14 sem seguir a jurisprudência de seu Tribunal ou de Tribunais Superiores. Tais tribunais, não raramente "além de discordarem entre si, não respeitam a sua própria jurisprudência”, o que, no Brasil, vem gerando um quadro caótico. Essa

\footnotetext{
${ }^{14}$ A liberdade concedida no sistema da civil law se destina ao Judiciário como um todo, a fim de adaptar o direito às alterações da sociedade e às peculiaridades do caso concreto, e não ao juiz individualmente considerado, já que este não pode adaptar o direito ao caso concreto à sua maneira pessoal. (WAMBIER; WAMBIER, 2009, p.08).
} 
liberdade do julgador, não lhe dá, contudo, o direito de julgar contrariamente às decisões do STF.

O fato de o juiz ordinário ter o poder-dever de controlar a constitucionalidade obviamente não significa que ele não deve respeito às decisões do Supremo Tribunal Federal. Este respeito decorre logicamente da adoção do sistema de controle difuso e da atribuição ao Supremo de dar a última e definitiva palavra acerca da constitucionalidade da lei federal. Quando se tem claro que a decisão é um mero sistema judicial, torna-se pouco mais do que absurdo admitir a possibilidade de o juiz ordinário contrariar as decisões do Supremo Tribunal Federal. (MARINONI, 2010, p.84).

Situações como estas comprometem o Estado de Direito "na medida em que as coisas passam a correr como se houvesse várias 'leis', regendo a mesma conduta: um clima de integral instabilidade e ausência absoluta de previsibilidade" (WAMBIER; WAMBIER, 2009, p.06), dificultando até mesmo saber-se qual a jurisprudência predominante. É exatamente para findar esta insegurança, que se defende a abstrativização analisada.

\subsection{Os prejuízos à primazia da Constituição}

Apesar de todos os benefícios elencados, extensas são as críticas a esta almejada objetivação. Baseando-se em Streck, Oliveira e Lima (2010), que sintetizam os principais argumentos, é possível afirmar que ela, se admitida no meio jurisprudencial ou legislativo, pode trazer grandes prejuízos ao ordenamento jurídico.

Primeiramente porque altera a competência privativa do Senado de outorgar efeito erga omnes às decisões de inconstitucionalidade em controle difuso (art. 52, X, da CF), de forma inconstitucional, ferindo a esfera de poder do Legislativo, enfraquecendo a força hierárquico-normativa da Constituição e criando um novo texto (não por "mutação constitucional"). Ora, "um tribunal não pode paradoxalmente subverter a constituição sob o argumento de está-la garantindo ou guardando" (STRECK, OLIVEIRA E LIMA, 2010, p.21).

Segundo, porque cria também a possibilidade de aprovação de declaração de inconstitucionalidade de lei pelo simples voto de seis Ministros, já que este é o quórum para julgamento de mérito do Recurso extraordinário - quórum menor inclusive que as súmulas vinculantes. Concede-se, assim, "um poder jamais visto no Brasil nas mãos do STF" (SCAFF apud STRECK; OLIVEIRA; LIMA, 
2010, p.04), permitindo que, por seis de seus integrantes, o STF exerça "o papel de árbitro último da política nacional" (VIEIRA apud SANCHEZ, 2008). ${ }^{15}$

Terceiro, registra-se grande ofensa ao princípio democrático, exigido pela Constituição Federal para dar legitimidade às declarações de inconstitucionalidade com efeito erga omnes, como se vê na legitimidade para a propositura de $\mathrm{ADIs}$, e no art. 52, X, CF, por exemplo. Com a objetivação do controle subjetivo, o STF é quem concederá tal efeito, mas sem ter a Constituição lhe atribuído qualquer legitimidade para tanto. "Significa, por fim, retirar do processo de controle difuso, qualquer possibilidade de chancela dos representantes do povo deste referido processo, o que não parece ser sequer sugerido pela Constituição da República de 1988" (STRECK; OLIVEIRA; LIMA, 2010, p.07).

Por fim, a abstrativização ofende também princípios constitucionais do devido processo legal, da ampla defesa e do contraditório, já que possibilita aplicar uma decisão àqueles que não tiveram garantido o seu direito constitucional de participação nos processos. Fere-se, portanto, direitos fundamentais, inclusive o acesso à justiça, em especial ao STF. (STRECK; OLIVEIRA; LIMA, 2010, p.28-29).

São fortes argumentos que denotam o desrespeito à Constituição brasileira, em vários aspectos, que não podem ser desconsiderado em um Estado que se declara "Constitucional de Direito".

\section{O PAPEL DAS SÚMULAS VINCULANTES}

Criada pela Emenda Constitucional n. 45/2004, as súmulas vinculantes surgiram no ordenamento jurídico brasileiro junto com a denominada "Reforma do Judiciário" que visou conferir eficácia e celeridade à prestação jurisdicional. A morosidade e a descrença no Judiciário são generalizadas e a reforma, buscando desafogar os tribunais, teve como objetivo precípuo reforçar o direito fundamental de acesso à justiça, garantido pelo art. $5^{\circ}, \mathrm{XXXV}$, da CF.

A criação destas súmulas segue a tendência mundial de racionalização da atividade jurisdicional, uniformizando a jurisprudência e acelerando os

\footnotetext{
${ }^{15}$ Entremeios às críticas à abstrativização, um alerta que cada dia mais amealha argumentos e adeptos no cenário acadêmico é o risco de assunção de poderes pelo STF. Quanto ao alegado ativismo, Moreira Alves, ex-ministro do STF, afirma que "hoje, o STF está adotando uma posição mais política que antigamente", e que este é "um papel irreversível", mas que "o problema aí é saber justamente se a Constituição outorga esse poder ou se ele foi criado pelo tribunal". (Carta não autoriza STF a criar norma, diz Moreira Alves, revista VALOR ECONÔMICO, 23 de agosto de 2011).
} 
julgamentos. Tal escopo já foi atingido, ao menos em partes, posto que nos primeiros anos de existência, a súmula vinculante - juntamente com outros institutos como a repercussão geral, foi responsável por grande redução do número de recursos aos tribunais superiores. (FALCÃO; CERDEIRA; ARGUELHES, 2010, p.59-62) Não restou comprovado ainda, contudo, se efetivamente as súmulas conferiram maior celeridade aos julgamentos judiciais como um todo, até mesmo porque, por via reflexa, geraram o aumento de outras modalidades processuais, como as reclamações constitucionais ajuizadas na Suprema Corte. ${ }^{16}$

\subsection{O efeito vinculante}

Muito embora as súmulas de efeito vinculante só tenham sido criadas em 2005, tal efeito já se encontrava presente no ordenamento jurídico brasileiro desde a edição da Emenda Constitucional n. 3/93. A partir da referida emenda, as decisões de mérito proferidas nas ações declaratórias de constitucionalidade (ADC), além de produzirem coisa julgada oponível erga omnes, passaram a ser dotadas também de efeito vinculante.

À época, houve divergência se este efeito atingiria também as ações diretas de inconstitucionalidade ${ }^{17}$, mas acabou prevalecendo o entendimento esboçado por Ives Gandra Martins (1995, p.95) de que o efeito vinculante é "inerente ao controle concentrado por qualquer uma das formas admitidas pelo texto constitucional [...] até porque as duas ações configuram facetas complementares do mesmo fenômeno de salvaguarda judicial da lei suprema". Tal prevalência foi ratificada pela Emenda Constitucional 45/2004, que incluiu o $\S 2^{\circ}$ ao art. 102 e declaradamente tornou as decisões de mérito das ADCs e das ADIs obrigatórias "relativamente aos demais órgãos do Poder Judiciário e à administração pública direta e indireta, nas esferas federal, estadual e municipal". Com isso, as decisões de mérito advindas do controle concentrado de constitucionalidade passaram a ter efeito vinculante e deixam de exigir, assim, a comunicação da decisão ao Senado para determinar sua suspensão -

\footnotetext{
${ }^{16}$ Sobre o assunto consultar ZAMARIAN (2011).

${ }^{17}$ O então Ministro do STF, Sepúlveda Pertence, por exemplo, expressou entendimento na Recl 621RS, DJU 04.07.1996, que o efeito vinculante só seria extensível às ADIs se naquele caso também fosse uma ADC, ou seja, somente se o objeto impugnado fosse ato normativo federal. (CLĖVE, 2000, p.242). Araújo e Nunes Jr. (2006, p.53) entendiam que não seria possível a extensão dos efeitos para a ADI, sem previsão constitucional específica "seria ferir a autonomia do juiz por lei ordinária, o que não encontra suporte constitucional".
} 
necessidade exclusiva das declarações de inconstitucionalidade por meio de controle difuso.

O efeito vinculante veio como um reforço ao Estado Democrático de Direito, já que a desobediência à jurisdição constitucional acarreta um "rompimento da estrutura da organização judiciária brasileira, instalando-se a insegurança no seio da tutela jurídica" (GOES, 2005, p.133). Pode ser garantido através da Reclamação Constitucional ${ }^{18}$, muito embora tal garantia não seja plena, segundo Leal, já que pode gerar um "inconveniente procedimento cíclico" (LEAL, 2006, p.166) de cassação da decisão divergente e persistência infinita da recalcitrância indesejada ${ }^{19}$. O descumprimento infundado da súmula, contudo, é um ato de insubordinação e pode gerar responsabilização do magistrado prática não recorrente na jurisprudência brasileira. Mesmo assim, a existência de um efeito vinculante e seu mecanismo de proteção acaba, ainda que em longo prazo, ceifando a adoção de tais posicionamentos pelos juízes de instancias inferiores. É como explica Moreira Alves:

Se souber que toda vez que julgar diferente o processo retornará, o próprio juiz se convencerá que tem que respeitar. Pode entender que sua independência vale muito, e demorar para reconhecer. Mas, quando tiver que decidir duas, três, quatro vezes, até chegar ao momento da exaustão. (ALVES apud LEAL, 2006, p.166).

É a constituição do que o Leal afirma ser um "importante mecanismo de inibição da renitência em face da determinação de novo julgamento" (LEAL, 2006, p.166). Este efeito vinculante não impede, todavia, que órgão legislativo edite novo ato com o mesmo conteúdo declarado inconstitucional e nem tampouco "congela" definitivamente a jurisprudência do STF, pois assim como nos EUA, a alteração da situação fática no Brasil autoriza a mudança de posicionamento sobre determinada matéria constitucional. (CLÈVE, 2000, p.240-241).

\footnotetext{
${ }^{18}$ Sobre o assunto consultar ZAMARIAN (2011).

${ }^{19}$ A súmula vinculante tem sido vista como alternativa para evitar a recalcitrância daqueles que insistem em desrespeitar a jurisprudência do STF. No tocante ao processamento e julgamento de civis denunciados pelo crime de falsificação da carteira de habilitação naval (CIR) ou habilitação de arraisamador, por exemplo, o Supremo entende que a competência é da Justiça Federal e visando obstar a constante inobservância deste posicionamento pelo Superior Tribunal Militar, na seção de 13 de setembro de 2011, a Segunda Turma sugeriu a elaboração de proposta de súmula vinculante como forma de impor sua observância, sob pena responsabilização do magistrado por desobediência.

(Noticias STF, Turma propõe súmula para que STM aplique jurisprudência do STF. Disponível em: <http://www.stf.jus.br>. Acesso em 13 de setembro de 2011).
} 


\subsection{As súmulas vinculantes e seu procedimento}

A Constituição Federal, ao possibilitar, em seu art. 103-A, a edição de súmulas pacificadoras da jurisprudência com poder de vincular os demais órgãos do Poder Judiciário e administração pública direta e indireta, nas esferas federal, estadual e municipal vinculantes, estabeleceu alguns critérios para sua aprovação. Para sua edição ou revisão é necessário que o procedimento seja iniciado de ofício por membros do próprio STF ou por provocação daqueles legitimados para propor ADI e ADC, cujo rol consta do artigo 103, CF, mas que, acusado de ser muito restrita ${ }^{20}$, foi ligeiramente ampliado através da lei $\mathrm{n}$. $11.417 / 2006^{21}$.

Mediante a iniciativa desses legitimados, deve ser apresentada Proposta de Súmula Vinculante (PSV) que necessita, impreterivelmente, ter como objeto a validade, interpretação e eficácia de normas ${ }^{22}$ de índole constitucional ${ }^{23}$. Deve tratar de controvérsia atual ${ }^{24}$ entre órgãos judiciários ou entre estes e a administração pública, que possa gerar grave insegurança jurídica ${ }^{25}$ e relevante multiplicação de processos sobre idêntica questão. A proposta será julgada pelo Plenário, que deverá aprová-la pelo voto de dois terços de seus Ministros. Tratase de quórum qualificado, também exigido para a revisão ou cancelamento, que impõe uma maior dificuldade na aprovação das súmulas ${ }^{26}$.

Uma vez aprovada, a súmula adquire eficácia imediata, passando, desde logo a vincular os demais órgãos do Poder Judiciário e administração pública direta e indireta, nas esferas federal, estadual e municipal vinculantes, muito embora deva ser publicada no prazo de dez dias.

\footnotetext{
${ }^{20}$ A restrição da legitimação democrática sofre duras críticas na doutrina: "A escolha destes legitimados não nos parece de todo acertada, visto que a súmula vinculante vem a solucionar controvérsia existente nos tribunais e estes não estão habilitados para deflagrar a discussão (...). Por que não permitir que as associações, ou qualquer outro grupo organizado, os cidadãos e outros grupos não organizados passem a participar deste processo de 'oxigenação' da interpretação constitucional? Por que não admitir que 'mais intérpretes não formais' participem da interpretação constitucional?" (LAMY; CONCI, 2005, p.310.)

${ }^{21}$ A Lei n. 11.417/2006 incluiu também no rol de legitimados ativos os Tribunais brasileiros (Tribunais Superiores, Tribunais de Justiça de Estados ou do Distrito Federal e Territórios, Tribunais Regionais Federais, Tribunais Regionais do Trabalho, Tribunais Regionais Eleitorais e Tribunais Militares), o Defensor Público-Geral da União e os Municípios que sejam partes em processo judiciais sobre a controvérsia da matéria constitucional passível de ser sumulada.

${ }^{22}$ Em tese, deve haver então dúvida sobre a aplicação de determinada norma, não sendo possível a edição de súmulas vinculantes em caso de lacunas legislativas. Apesar de tal exigência, note-se a Súmula Vinculante n.11, que dispõem sobre o uso de algemas, foi exatamente editada sobre matéria relegada a legislação inexiste. Muito embora o art. 199, da Lei n. 7210/1984, disponha que o emprego de algemas será disciplinado por Decreto Federal, não há qualquer legislação sobre o assunto e, neste caso, a súmula vinculante acaba de prestando ao controle de constitucionalidade por omissão.
} 


\subsection{As súmulas como mecanismo de concessão de efeitos abstratos às decisão de controle difuso}

Sendo a abstrativização uma medida positiva, já que pode trazer tantos benefícios ao direito fundamental do cidadão de acesso à Justiça, posto que tem o condão de colaborar pra uma prestação judicial célere, eficaz, e mais homogênea, porque não então aplicá-la? Mas como resolver os problemas de sua inconstitucionalidade?

As súmulas vinculantes constituem-se em uma "ponte entre o controle difuso-concreto e o controle abstrato-concentrado (TAVARES, 2007, p.14)" e, em assim sendo, surgem como a melhor alternativa para resolver este paradoxo, sem qualquer alteração constitucional. Toda vez que o STF vislumbrar a necessidade de concessão dos efeitos erga omnes e vinculantes a decisões oriundas do julgamento de ações subjetivas, basta remetê-las ao Plenário e lá então, depois de cumpridos os requisitos constitucionalmente exigidos, editar súmula vinculante sobre a matéria.

Não deixa de ter razão, contudo, Marinoni quando afirma que a observância aos precedentes do Supremo, por ser a máxima Corte brasileira, deveria se dar simplesmente pela igualdade, segurança jurídica e previsibilidade, independentemente de edição de súmula vinculante:

\footnotetext{
${ }^{23}$ Com a utilização da expressão "matéria constitucional", abrange-se não só a norma constitucional propriamente dita - as primárias e secundárias, mas também as leis e atos normativos questionados em face ao texto constitucional. É o que se depreende do entendimento expressado por Medina, Wambier e Wambier (2007) e Tavares (2007, p.14).

${ }^{24} \mathrm{O}$ termo atual é aberto e a norma não define o lapso temporal necessário para que se afira a atualidade daquela controvérsia. Exclui-se, de qualquer forma, a possibilidade de edição de súmula sobre matérias já pacificadas, ultrapassadas ou até com entendimento já alterado pelo próprio STF, posto que neste caso, seria desnecessária e inútil. Segundo Tavares (2007, p.40), esta atualidade deve ser aferida tanto no momento da propositura da proposta de elaboração de súmula vinculante, como na efetiva criação do enunciado.

${ }^{25}$ A grave insegurança jurídica está intimamente relacionada com a quantidade de pessoas possivelmente afetadas por aquela norma objeto da súmula, sempre que o posicionamento dos órgãos judicantes for tão disforme que os próprios jurisdicionados não puderem identificar, com clareza, quais são seus direitos e/ou deveres com relação àquela determinada norma (LAMY; CONCI, 2005, p.310). Estará também presente também quando a questão constitucional for relativa a direitos fundamentais, ou, como advertem Zeno Veloso e Gustavo Vaz Salgado (2005), quando forem violados de direitos constitucionais de outra natureza.

${ }^{26}$ Exige-se o quórum qualificado para a aprovação das súmulas vinculantes, mas a norma constitucional não o exige nas reiteradas decisões basilares. Tal dispensa é criticada por Tavares (2007, p.45 e ss): “i) o quorum exigido para alcançar essas decisões pode ter sido frágil demais para justificar a transposição (do concreto para o geral-vinculante) representada pelo processo decisório da súmula vinculante; ii) o fundamento da decisão em cada caso concreto prévio pode não ser único, embora cheguem todos ao mesmo resultado final para a ação ou recurso proposto (isso é particularmente grave no caso de controle de constitucionalidade)". Streck (2004, p.187) afirma, contudo, que este quórum é sim exigível destas reiteradas decisões.
} 
Na verdade, o sistema de súmulas, como única e indispensável forma para a vinculação dos juízes, é contraditório como fundamento que, embora não explícito, justifica o respeito obrigatório aos precedentes constitucionais. $\mathrm{O}$ que se justifica o respeito aos precedentes é a igualdade, a segurança jurídica. De modo que, em princípio, uma simples decisão tomada pelo Pleno do Supremo Tribunal Federal, não importa a qualidade da maioria obtida, não pode deixar de vincular o próprio Tribunal e os demais tribunais e juízes. Ao á razão lógica para se exigirem decisões reiteradas a menos que se parta da premissa de que o Supremo Tribunal Federal não se importa com a força de cada uma das suas decisões e supões não ter responsabilidade perante os casos futuros. Tal premissa, ainda que pudesse ser válida dentro de um sistema puro de civil law, é incompatível com um sistema estruturado sob o controle difuso da constitucionalidade, que, necessariamente deve contar com uma Corte superior capaz de fazer prevalecer as suas decisões sobre si e os demais juízes para imprimir força à Constituição e coerência à ordem jurídica, bem como dar segurança jurídica e previsibilidade aos jurisdicionados.

Ademais, decisão tomada por maioria do Pleno do Supremo Tribunal Federal, ainda que não de dois terços, seguramente constitui decisão que não pode deixar de se impor a ele próprio e aos demais juízes. A circunstância de uma Suprema Corte poder revogar os seus próprios precedentes, como costumeiramente acontece nos Estados Unidos, nada tem a ver com o fato de o precedente ser oriundo de caso que se repetiu ou de a decisão ter sido tomada por maioria simples ou por maioria qualificada. O que pode justificar a revogação de um precedente, por exemplo, é a mutação da realidade social que a Corte considerou ao decidir.

A compreensão da necessidade de cada uma das decisões do Supremo Tribunal Federal vincular o próprio tribunal e os demais juízes advém da premência de dar sentido à função da mais alta Corte brasileira diante do controle de constitucionalidade. Não há racionalidade em supor que apenas algumas de suas decisões, tomadas no controle difuso, merecem ser respeitadas pelo próprio tribunal e pelos demais juízes, como se o jurisdicionado não devesse confiar nas decisões do Supremo antes de serem sumuladas. Ora, isso seria o mesmo que supor que a segurança jurídica e a previsibilidade dependeriam das súmulas e, por consequência, que o próprio Poder Judiciário, diante do sistema ao qual é submetido, não teria capacidade de responder aos seus deveres e aos direitos fundamentais do cidadão perante a justiça. (MARINONI, 2010, p.79-80).

Isto não pode ocorrer, contudo, se de forma contrária à Norma Constitucional vigente. Ora, se a partir da Emenda n. 45/2004, já existem meios 
para que o STF pudesse conceder efeitos mais abstratos às formas de controle difuso de constitucionalidade, não há porque o julgador, em especiais, os Ministros da nossa Corte Máxima, criar um mecanismo alheio com a mesma finalidade.

É imprescindível preservar a primazia da Constituição e, se ela já descreve um meio de se conceder efeitos abstratos às decisões de controle difuso, não podem os Ministros do STF simplesmente "criar" um novo método sem observálo. São nobres as justificativas de economia, celeridades processuais e até mesmo segurança jurídica, mas porque não respeitar o procedimento constitucional previsto e editar uma súmula vinculante sobre a matéria?

Isso impedirá que o Supremo aja com abuso de poder, mas também beneficiará o cidadão com a celeridade e uniformização através de um procedimento previsto na Norma Fundamental brasileira.

Deve-se então observar o quórum mínimo de aprovação por $2 / 3$ dos votos do total dos Ministros, como previsto para a Súmula vinculante.

Ora, uma decisão que não reúne sequer o quorum para fazer uma súmula não pode ser igual a uma súmula (que tem efeito vinculante - e, aqui, registre-se, falar em "equiparar" o controle difuso ao controle concentrado nada mais é do que falar em efeito vinculante). (STRECK; OLIVEIRA; LIMA, 2010, p.10).

O legislador constituinte já previu este quórum qualificado para a concessão de efeitos vinculantes a decisões subjetivas pelo próprio STF, sem participação do Senado Federal. Este quorum deve ser respeitado sob pena de inconstitucionalidade e invasão de competência do Senado Federal.

Devem também ser preenchidas todas as demais exigências para a edição de súmulas vinculantes. Mas sob esta teoria defendida, e como ficaria então o requisito das reiteradas decisões?Tal requisito é elencado como essencial para a edição de uma súmula vinculante pelo art. 103-A da Constituição Federal. Como se trata de um conceito aberto, sem definição legal, fica difícil quantificar quantas decisões são necessárias para preencher o termo "reiteradas". Sob esta pecha, o STF já chegou a editar súmula vinculante baseado em uma única decisão anterior ${ }^{27}$, mas tal inobservância à norma constitucional não pode servir de desculpa para se permitir edição de súmula vinculante para abstrativizar qualquer decisão obtida em controle difuso de constitucionalidade.

\footnotetext{
${ }^{27}$ É o caso da súmula vinculante n. 28, que teve como único precedente a ADI 1074. Note-se que outras oito súmulas vinculantes já foram editadas com base em não mais que 4 decisões anteriores, é o caso das súmulas n. $1,3,5,11,18,20,22$, e 32 .
} 
É necessário que tenham sim havido reiteradas decisões. Este foi um requisito criado pelo legislador constituinte para garantir um mínimo de segurança jurídica ao jurisdicionado e não pode ser ferido pelo STF, nem mesmo com a justificativa de mera abstrativização, sob pena de se constituir ato político e trazer desorganização judiciária.

Para a prevalência e aplicação da abstrativização como defendida por Marinoni, imprescindível seria uma reforma constitucional. Caso contrário, a tentativa de "abstrativização" pura e simples pelo próprio STF caracteriza-se como forma de burlar o procedimento das súmulas vinculantes, que ficará praticamente esvaziado caso prevaleça esse fenômeno objeto da atividade criativa da Suprema Corte brasileira. A Constituição é norma que goza de supremacia e, não se pode ferir seu texto expresso sob a pecha de garantir-lhe força.

Não pode a Suprema Corte criar um novo procedimento, sem participação legislativa, sob pena de arriscar até mesmo o propósito do Direito: a pacificação social. Esta, por sua vez, só será atingida, a partir do momento em que os jurisdicionados tenham o conhecimento do sistema jurídico e do sistema de julgamento, para que se opere então a legitimação pelo procedimento, como defende Niklas Luhmann (1980). Deve haver uma certeza do procedimento a ser adotado, não do resultado, mas do procedimento ao qual será submetido. Este é um dos requisitos para que exista uma aceitação geral dos jurisdicionados no procedimento daquele sistema jurídico - apto a lhe fornecer uma solução.

Isso não existirá com o STF inovando na criação de procedimentos inexistentes na legislação para a alteração dos efeitos de algumas de suas decisões.

Para ser abstrativizada deve então a decisão advinda do controle difuso de constitucionalidade respeitar todas as exigências constitucionais para a edição de súmula vinculante, e, caso não a cumpram, não poderá ganhar efeito erga omnes pelas mãos do STF, mas tão somente com a participação do Senado Federal nos moldes do art. 52, X, da CF.

\section{CONCLUSÃO}

O Supremo Tribunal Federal vem, cada dia mais, amealhando poderes para si. Por tal motivo é que inúmeras são as acusações de ativismo judicial e atuação legislativa. Seus poderes em relação ao controle de constitucionalidade, 
em especial, vêm sendo ampliados e a tentativa de abstrativização das decisões sem qualquer previsão constitucional é uma amostra disso tudo.

A abstrativização pode sim ser benéfica, mas não pode ser imposta em desrespeito à norma constitucional. Não se despreza a imprescindibilidade de respeito e prevalência às decisões, qualquer delas, da mais alta Corte do país. Mas não se pode admitir, contudo, que o Supremo crie um procedimento próprio, restringindo a análise de recursos e impondo uma única decisão a várias outras demandas, sem que esta seja a vontade do legislador constituinte.

A saída proposta é a edição de súmulas vinculantes toda vez que se os Ministros entenderem necessária a extensão de uma decisão proferida em controle difuso de constitucionalidade pelo STF. A decisão do processo subjetivo deverá ser remetida ao Plenário, e lá aprovada por 2/3 dos Ministros, para que então, se preenchendo todos os demais requisitos do art.103-A, CF, operar efeito erga omnes e vinculante.

\section{REFERÊNCIAS}

ARANTES, Rogério Bastos. Judiciário e Política no Brasil. São Paulo: Sumaré, 1997.

ARAÚJO, Luiz Alberto; NUNES JR., Vidal Serrano. Curso de direito constitucional. 10.ed. São Paulo: Saraiva, 2006.

BARROSO, Luis Roberto. Curso de direito constitucional

contemporâneo: os conceitos fundamentais e a construção do novo modelo. São Paulo: Saraiva, 2009.

BARROSO,Luís Roberto. O controle de constitucionalidade no direito brasileiro. 3.ed. São Paulo: Saraiva, 2008.

BONAVIDES, Paulo. Curso de Direito Constitucional. São Paulo: Malheiros editores, 1994.

CANOTILHO, Jose Joaquim Gomes. Direito constitucional e teoria da constituição. 5.ed. Coimbra: Livraria Almedina, 1991.

CAPPELLETTI, Mauro. O controle judicial de constitucionalidade das leis no direito comparado. 2.ed. Trad. Aroldo Plínio Gonçalves. Porto Alegre: Fabris, 1999. 
CLÈVE, Clemerson. A fiscalização abstrata da constitucionalidade no direito brasileiro. $2^{a}$ ed. rev. atual. e ampliada. São Paulo: RT, 2000.

DIDIER JÚNIOR, Fredie. Transformações do recurso extraordinário. In: FUX, Luiz; NERY JUNIOR, Nelson; WAMBIER, Teresa Arruda Alvim. Processo e Constituição: estudos em homenagem ao prof. Coord. José Carlos Barbosa Moreira. São Paulo: Revista dos Tribunais. 2006.

FALCÃO, Joaquim; CERDEIRA, Pablo de Camargo; ARGUELHES, Diego Werneck. O Supremo em números. FGV. Abril de 2011. Disponível em: $<$ http://www.supremoemnumeros.com.br>. Acesso em: 06 ago. 2011.

FAVOREU, Louis. As cortes constitucionais. Trad. Dunia Marinho Silva. São Paulo: Landy, 2004.

GÓES, Gisele Santos Fernandes. A reclamação constitucional. In: NERY JR., Nelson; WAMBIER, Teresa Arruda Alvim; (coord.). Aspectos polêmicos e atuais dos recursos cíveis e de outros meios de impugnação às decisões judiciais. São Paulo: Revista dos Tribunais, 2005. V. 8.

GOMES JÚNIOR, Luiz Manoel. A repercussão geral da questão constitucional no recurso extraordinário. Revista do Processo, São Paulo, n.142, p. 91-116, jan. /2005.

KELSEN, Hans. Teoria pura do direito. Trad. João Batista Machado. $7^{\mathrm{a}}$ Ed. São Paulo: Martins Fontes, 2006.

LAMY, Marcelo; CONCI, Luiz Guilherme Arcaro. Reflexões sobre as Súmulas Vinculantes. In: TAVARES, André Ramos; LENZA, Pedro; ALARCÓN, Pietro de Jesus Lora (coord.). Reforma do Judiciário analisada e comentada. São Paulo: Método, 2005.

LEAL, Roger Stiefelmann. O efeito vinculante na jurisdição constitucional. São Paulo: Saraiva, 2006.

LUHMANN, Niklas. Legitimação pelo procedimento. Brasília: UnB, 1980. 
MARINONI, Luiz Guilherme. Precedentes obrigatórios: crítica entre as jurisdições do civil law e common law. São Paulo: RT, 2010.

MARINONI, Luiz Guilherme; MITIDIEIRO, Daniel. Repercussão geral no recurso extraordinário. São Paulo: Revista dos Tribunais, 2007.

MARTINS, Ives Gandra. Distinção entre suspensão de vigência e eficácia de norma inconstitucional e materialidade do direito suspenso em processo cautelar de ação direta de inconstitucionalidade com liminar concedida. In: Revista do Tribunal Regional Federal da $1^{\text {a }}$ Região. Brasília, 7(2):93-107, abr/jun. 1995.

MEDINA, José Miguel Garcia, WAMBIER, Luiz Rodrigues e WAMBIER, Teresa Arruda Alvim. A Súmula Vinculante, vista como meio legítimo para diminuir a sobrecarga de trabalho dos tribunais brasileiros. Revista do Advogado, Ano XXVII, n. 92, julho de 2007.

MENDES, Gilmar Ferreira. O papel do Senado Federal no controle de constitucionalidade: um clássico de mutação constitucional. Revista de informação legislativa, n.162, abr./jun. 2004a.

MENDES, Gilmar. Direitos fundamentais e controle de constitucionalidade: estudos de direito constitucional. São Paulo:

Saraiva, 2004b.

MIRANDA, Jorge. Um contributo para uma Teoria da Inconstitucionalidade. Coimbra: Coimbra editora, 1996.

MORAES, Alexandre de. Direito Constitucional. $8^{\text {a }}$ ed. São Paulo: Atlas, 2000.

SANCHEZ, Rafael Cavinato. O efeito erga omnes no controle difuso de constitucionalidade. Universitária: Revista do curso de mestrado em direito, Centro universitário Toledo. v.1, n.1, jul/2000. Araçatuba: Centro Universitário Toledo, 2008.

STRECK, Lenio Luiz. Comentários à reforma do Poder Judiciário. In: AGRA, Walber de Mouta Agra (coord.). Rio de Janeiro: Forense, 2004. 
STRECK, Lenio Luiz; OLIVEIRA, Marcelo Andrade Cattoni; LIMA, Martonio Mont'Alveme Barreto. A nova perspectiva do Supremo Tribunal Federal sobre o controle difuso: mutação constitucional e limites da legitimidade da jurisdição constitucional. Disponível em $<\mathrm{http}$ :// www.leniostreck.com.br>. Acesso em 02 de setembro de 2010.

TAVARES, André Ramos. Nova Lei da Súmula Vinculante: estudos e comentários à Lei 11.417, de 19.12.2007. São Paulo: Método, 2007.

WAMBIER, Luiz Rodrigues; WAMBIER, Teresa Arruda Alvim. A Uniformidade e a estabilidade da jurisprudência e o Estado-de-Direito.

Cadernos Jurídicos, Curitiba, n.3, p.6-8, jun/2009.

WAMBIER, Luiz Rodrigues; WAMBIER, Teresa Arruda Alvim; MEDINA, José Miguel Garcia. Breves comentários à nova sistemática processual civil - leis 11.382/2006, 11.417/2006, 11.418/2006, 11.341/2006, 11.419/2006, 11.441/2007 e 11.448/2007. São Paulo: Revista dos Tribunais, 2007. v.3.

ZAMARIAN, Lívia Pitelli. Reclamação constitucional e eficácia das decisões do STF em controle de constitucionalidade: o novo papel assumido face à abstrativização do controle concreto. In: Anais do XX Encontro Nacional do CONPEDI. 2011. Florianópolis: Fundação Boiteux, 2011, p.11124-11147.

Recebido em: 2012-02-27 Aprovado para publicação em: 2012-06-12

Como citar: ZAMARIAN, Lívia Pitelli; NUNES JR, Vidal Serrano. Súmulas vinculantes: solução para a adequada abstrativização do controle difuso de constitucionalidade? Scientia Iuris, Londrina, v.16, n.1, p.113-136, jul.2012. DOI: 10.5433/21788189.2012v16n1p113. 